\title{
Special child, special mother: the sense of strength in mothers of children with congenital zika virus syndrome
}

\author{
Filho especial, mãe especial: o sentido da força de mães de crianças com a síndrome congênita do \\ zika vírus
}

\author{
Hijo especial, madre especial: el sentido de la fuerza de madres de niños con el síndrome congénito por \\ el virus del zika
}

Graziela Brito Neves Zboralski Hamad ${ }^{1}$ Kleyde Ventura de Souza ${ }^{2}$

1 Universidade Federal de Campina Grande, Campina Grande, PB, Brasil

2 Universidade Federal de Minas Gerais, Belo Horizonte, MG, Brasil
Corresponding author:

Graziela Brito Neves Zboralski Hamad

E-mail: grazielahamad@gmail.com

Submitted on $02 / 13 / 2019$.

Accepted on 06/13/2019.

DOI: 10.1590/2177-9465-EAN-2019-0022

\begin{abstract}
Objectives: To understand the meanings of having a child with the Congenital Zika virus Syndrome in the experience of women and, from this, what they would say to others who find themselves in the same situation. Method: Qualitative and interpretive study, based on the Model of Resilience, Stress, Adjustment and Family Adaptation proposed by McCubbin and McCubbin. 40 mothers from different cities in the state of Paraiba took part in the study. Results: The meanings found were classified in three thematic categories: the divine force that transforms life of the mothers; patience and love, double feelings as a source of overcoming; and the sense of mother's strength beyond the disease. Conclusion and implication for practice: Caring for a child diagnosed with Congenital Zika virus Syndrome has involved emotional, social, spiritual and economic aspects, as well as a transformation and suffering process. The experiences may contribute to the qualification of healthcare professionals who deal directly with these mothers, and possibly, favor the confrontation and adaptation of them and their families and of the new families that may come to have children with
\end{abstract}

Keywords: Pregnancy; Zika virus; Microcephaly; Epidemics; Child.

\section{Resumo}

Objetivos: Compreender os significados de ter um filho com a Síndrome Congênita do Zika vírus na experiência de mulheres e, a partir disso, o que elas diriam a outras que se encontrem na mesma situação. Método: Estudo qualitativo e interpretativo, fundamentado no Modelo de Resiliência, Estresse, Ajustamento e Adaptação Familiar proposto por McCubbin e McCubbin. Participaram da pesquisa 40 mães de diferentes cidades do estado da Paraíba. Resultados: Os significados encontrados foram classificados em três categorias temáticas: a força divina que transforma a vida das mães; paciência e amor, sentimentos em dobro como fonte de superação; e o sentido da força das mães para além da doença. Conclusão e implicação para a prática: Cuidar de um filho com diagnóstico da Síndrome Congênita do Zika vírus tem envolvido aspectos emocionais, sociais, espirituais e econômicos, além de um processo de transformação e sofrimento. As experiências poderão colaborar com a qualificação da assistência em saúde dos profissionais que lidam diretamente com essas mães, e possivelmente favorecer o enfrentamento $e$ a adaptação delas e de suas famílias e das novas famílias que poderão vir a ter filhos com a síndrome.

Keywords: Gravidez; Zika vírus; Epidemias; Microcefalia; Criança.

\section{Resumen}

Objetivos: Comprender los significados de tener un hijo con el Síndrome Congénito por el Virus del Zika en la experiencia de mujeres y, a partir de esto, qué dirían estas a otras que se encuentren en la misma situación. Método: Estudio cualitativo e interpretativo, fundamentado en el Modelo de Resiliencia, el estrés, el ajuste y la adaptación familiar propuesto por McCubbin y McCubbin. Participaron en la investigación 40 madres de diferentes ciudades del estado de Paraíba. Resultados: Los significados encontrados se clasificaron en tres categorías temáticas: la fuerza divina que transforma la vida de las madres; paciencia y amor, sentimientos duplicados como fuente de superación; y el sentido de la fuerza de las madres más allá de la enfermedad. Conclusión e implicación para la práctica: Cuidar a un hijo con el diagnóstico del Síndrome Congénito por el Virus del Zika involucra aspectos emocionales, sociales, espirituales y económicos, además de un proceso de transformación y sufrimiento. Las experiencias podrán colaborar con la cualificación de la asistencia en salud de los profesionales que tratan directamente con estas madres, y posiblemente esto también favorece la lucha y la adaptación de ellas, de sus familias y de las nuevas que vendrán que puedan llegar a tener hijos con este síndrome.

Keywords: Embarazo; Virus del Zika; Microcefalia. Epidemias; Niño 


\section{INTRODUCTION}

During the gestational period, women prepare for the birth of the child, experiencing moments of personal fulfillment, satisfaction, happiness, expectations, but, also, worry, anxiety, doubts, anguish, insecurities and fear. Pregnancy is a significant event for women and their families. ${ }^{1-2}$ With the arrival of a baby with congenital malformation, feelings arise that break with the idealization of a perfect child, accentuating the gap between what one imagined and/or desired and what presents itself in reality, bringing to light the transformation of the imagined reality, in a very particular way for the mothers - and those who with her were involved with it, generating an emotional exhaustion, with alterations in plans and routines, ${ }^{1}$ and life.

Society establishes and values standards of strength, effectiveness, beauty and perfection, with emphasis in the child's efficiency and health. ${ }^{3}$ In general, the child is not expected to get sick, however, when there is no favorable prognosis, this situation can be considered hopeless, especially when there is a possibility that the child may die,${ }^{4}$ or live in a sickness situation. It began in the Brazilian northeast, triggering a strong social commotion in Brazil, marking a before and after in women lives, whose children were affected by microcephaly associated with neurological and cognitive alterations, as a consequence of congenital infection by Zika virus. ${ }^{5-6}$

In August 2015, neuropediatricians from public hospitals in Recife/Pernambuco, Brazil, identified an increase in microcephaly cases associated with brain anomalies, observing, from there on, what would become a new nosological entity. Such a fact was set up as a possibility for an unique experience. ${ }^{6}$ However, while the relationship between Zika virus and microcephaly was investigated, researchers have pointed out that it could be a congenital syndrome with several symptoms, with neurological impairment at birth, and may be accompanied by several complications. The Congenital Zika virus Syndrome (CZVS) started to be described. ${ }^{7}$ The situation worsened and, in February 2016, the World Health Organization (WHO) issued a global emergency situation. ${ }^{8}$

Microcephaly is the most conspicuous feature of the CZVS, which encompasses signs and symptoms that compromise brain development and adequate central nervous system function in newborns. ${ }^{9}$ Thus, in the reported cases, it became important to deepen the knowledge about the Zika virus in pregnancy and its possible implications, to plan actions regarding prevention and promotion to the health of the mother and the newborn, as well as to offer prenatal follow-up of infected pregnant women. ${ }^{10}$

The effects of infection caused by the virus struck the population, researchers, professionals and health authorities in Brazil and in the world. ${ }^{11}$ A study accomplished in João Pessoa/ PB, among mothers of children with microcephaly, revealed that, when they became aware of the knowledge regarding the diagnosis, many doubts have emerged about the disease, since its origin, probable consequences for the baby, as well as uncertainty about treatments and sequelae, ${ }^{12}$ highlighting that it is necessary to know more about the Zika virus and its possible complications, ${ }^{13}$ as well as the effects and repercussions on the lives of women, mothers of children in this condition, their families, and, in an ampler instance, the implications for the (re) organization of the system, services and actions in healthcare, besides social mobilization.

The Zika virus epidemic showed a concrete effect on the lives of these women, mostly poor, living in northern regions of the country. ${ }^{14}$ Given an infection for which there is no specific protection and with teratogenic potential, data inaccuracy and lack of knowledge on the virus, as well as its consequences may influence directly on the vulnerability of mothers, emerging, during pregnancy, the fear that the child might be affected by microcephaly. ${ }^{12-3}$ From the CZVS diagnosis, coping and adaptation become important concerns, once that it affects children of women who live with the mosquito vector as part of everyday life for more than four decades, making difficult the understanding and acceptance of the consequences today. ${ }^{15}$

In a research, in the first reference hospital in Campina Grande/PB, women recognized themselves as a community of victims for the epidemic, comparing the effects of Zika virus on their children, also explaining the relation of the sequelae in children with the infection at the beginning of the gestation. ${ }^{15}$

Thus, what is included in the dictates of the constitutional text on health gets meaning, a right of all and a duty of the State, in particular the universality and decentralization of the policies, adding the accountability of the State assuring access to health conditions, adjusted to the fundamental social rights settled in the same Constitution and attuned to the Brazilian constitutional order. ${ }^{16}$ In the case of Zika virus infection, given its complexity, the challenge is to ensure that assistance is provided in SUS. ${ }^{17}$

It worth noting, based on the average annual prevalence of microcephaly related to infection by the Zika virus in the states of the Northeast Region, Brazil, in 2015-2016, that the State of Pernambuco was recognized as the epicenter of the epidemic, accompanied by the State of Bahia, considering the number of cases, compared to other states in the Northeast that were affected by the epidemic in the same period. High prevalence rates were also found in Paraíba (27.3/10 thousand live births), locus of this study. ${ }^{17}$

At the end of 2015, at Campina Grande/Paraíba, Brazil, in a hospital of the municipality, the Microcephaly Ambulatory was inaugurated..$^{15} \mathrm{~A}$ national and international circulation documentary addressed the issue, focusing women's struggle from the diagnosis confirmation. ${ }^{14}$

From this perspective, research must increase knowledge and understanding about the problems that are imposed on the life of the mothers and that by the acquired experience may produce senses for other mothers in the same situation. The term "experience" was chosen from its etymology and its uses in diverse Western languages, with a meaning that extends in two possible directions, from the knowledge acquired with the practice and from the emotional experience that is inherent to accumulating this knowledge. The experience is more related to the senses of the human body than with the thinking, determined by the contact with the real. ${ }^{18}$ 
Thus, it was sought to evidence the experience of mothers of children affected by the CZVS, and, from this, what they would say to others who find themselves in the same situation. Listening to what these women would have to say to others reminds us of the care, which signals attitudes that engender care, solicitude and attention that binds us to the other one; also, concern, restlessness and (dis) comfort, putting in relation those who care and those who are/should be cared for. ${ }^{19}$ Thus, when listening to them, it is possible to understand the reality in a broader form and how they have passed through the situation.

From this uneasiness, the place for the speech of these mothers was recognized, both in producing knowledge, as well as in negotiating uncertainties imposed on them by the biomedicine. Thus, they are (re) constructing their own mothering, as well as (re) mean what can be called special in relation to their children ${ }^{15}$ and to themselves - special mothers, both in their singularities.

It is believed that the experiences for mothers of the first generation of children with CZVS can contribute to expanding perspectives and qualifying care in the face of a new outbreak that may come to occur and that these women may expand these experiences a little. To do so, we use the research question: "What mothers of children with Congenital Zika virus Syndrome would say to pregnant women of children with a microcephaly diagnosis associated with Zika virus?", which originated the objective of this study, which was: To understand the meanings of having a child with the Congenital Zika virus Syndrome in the experience of women and, from that, what they would say to other women who find themselves in the same situation.

\section{METHOD}

A qualitative study, in which the interpretative description method assumptions were used. The qualitative approach seeks to unveil the phenomenon by itself, being explained as a universe of deep meanings, longings, beliefs, values and attitudes, widely used in life histories, where meaningful human constructions can not be perceived nor be captured in quantitative studies. ${ }^{20}$ From the narratives, we find the ideal approach to understand the organization, the socialization process, the emergency situation found in a group, as well as the situational responses to the usual contingencies. ${ }^{21}$

The interpretive description is considered a methodological approach, which has contributed to the understanding on the human health and the experience of diseases that imply in consequences and has been used as a basis to support several Nursing studies. ${ }^{22}$

The study was developed at the Specialized Rehabilitation Center (SRC) of Campina Grande/PB, that is a reference, in Paraíba, in the care of people with all types of disabilities, including children children with Congenital Zika Syndrome, having approximately 100 registered children, therefore, chosen as a research site. Currently, more than 2,800 people from 183 different municipalities are being cared. Of the registered patients, 800 are from Campina Grande and the others, coming from several areas of the state, such as Sertão, Curimataú and Cariri.. ${ }^{23}$ The service has an accredited multidisciplinary team and several services, such as aquatic physiotherapy and occupational therapy. The pregnant women and/or the children diagnosed with CZVS are referred by the professionals of the Basic Health Units, where they receive specialized care, undergo exams and, if confirmed, begin follow-up.

The Specialized Rehabilitation Center (SRC) started operation in February 2017 and did not have an updated record of the enrolled children who had CZVS, which made it difficult to approach the mothers initially. The contact with the participants was made at the institution itself and the selection was made by convenience, according to the mothers' time availability and the desire to contribute voluntarily to the research. The approach occurred in the service's waiting room from an informal conversation, at which time there was an approximation that made possible to present the research nature.

The inclusion criteria for taking part in the research were: women over 18 years old affected by Zika virus in the gestation (confirmed by laboratory exam) and children diagnosed with Congenital Zika Syndrome. Women whose children had microcephaly associated with other causes, women with some kind of cognitive inability to take part in the research, who did not reside in the state of Paraíba and who were not registered and attended at the Specialized Rehabilitation Center, as well as mothers of children accompanied by other relatives in the care, were excluded.

For the invitation to the mothers, the researcher found, in an informal conversation, whether she met the proposed inclusion criteria, mainly because many children did not have characteristics that are typical to microcephaly. With some mothers, the approach was hampered by time constraints, due to the established transportation schedules for return to their homes, often located in other municipalities. In total, 48 women were approached. Among these, two women expressed disinterest in taking part in the research; one of them mentioned having already participated in many surveys with long questions; in a unique situation, there was a mismatch between the researcher and the invited participant, emphasizing that this woman reported being "attacked" and preferred to leave the interview for another opportunity, but the meeting did not happen. Another five women were excluded because they did not meet the inclusion criteria: two of them were not the mothers of the children under the care and three reported not being confirmed if the diagnosis on the children would be associated with Zika virus. At the end, 40 women, mothers of 43 children, took part in the study because, of these, three had twin pregnancies.

The data collection was carried out during the months of June to November, 2017, through a semi-structured interview elaborated by the researcher, having as theoretical reference the Model of Resilience, Stress, Adjustment and Familiar Adaptation proposed by McCubbin and McCubbin, ${ }^{17}$ which aims to explain the potential of the family (in this study, we choose the mother as the central figure for the family) to deal with crisis situations and to understand factors related to adjustment and adaptation to the disease. Given a stressful event, in this case, the CZVS, she tries to maintain the equilibrium, and for such she uses the resources 
at her fingertips. The families are considered resilient when they successfully combat adversity and/or stress, or when they are able to reorganize their working patterns to meet new challenges.

For data collection, a quiet and reserved environment was guaranteed, with privacy of researcher and interviewed throughout the whole period, taking into account the measures for preventing and minimizing risks. The interviews had an average duration of 20 minutes and 47 seconds, the longest interview lasted 1 hour, 9 minutes and 29 seconds and the shortest interview lasted 9 minutes and 22 seconds.

These interview-mediated encounters sought to understand the meanings of having a child with the Congenital Zika virus Syndrome in women experience, and from that, what would they say to other pregnant women in the same situation. In this way, we try to identify singularities from each experience, in the midst of silences, cries, anguish, fear, ignorance, resignation, but also, the force expressed by the participants.

In order to facilitate the narrative-obtaining process, the questions and answers were recorded with the help of digital media, guaranteeing the confidentiality as a matter of priority. The questions could allow a spontaneous report, capable for generating sufficient elements for the researcher to transcribe and interpret them later. The interviews were fully transcribed, maintaining all language vices, interruptions, speeches of the researcher and speeches of the participants. The second step was to perform a reading of the transcribed data, which allowed a process for organizing the discourses into narratives.

By attending numerous types of deficiencies and congenital malformations and not having a certain day for each problem, as well as the researcher did not have access to a service agenda, it became necessary to move several times to the place, in search of the participants, attending the field as many times as necessary during data collection period, in order to address as many women as possible.

The final sampling was done by theoretical saturation, when it was noticed that there was no further increase in the obtained information. The saturation of the interviews is operationally defined as suspending the inclusion of new participants when the data obtained began to display repetition and redundancy. For such, eight steps were used to settle up data saturation criteria: make available the raw data records; immerse in each record; compile the individual analyzes; gather the themes or types of statements for each pre-category or new category; codify the data; allocate themes and types of statements; check the theoretical saturation for each pre-category or new category; and display the saturation. ${ }^{25}$

In order to preserve anonymity in the transcripts, we adopted the following identification form: for mothers, the initial $\mathrm{M}$ was used, followed by the ordinal numeral which represents the order in which the interviews were performed (M1, M2, ... M10), and so on

For analyzing the material, the Content Analysis technique of the thematic type proposed by Bardin was used, ${ }^{26}$ defined as a set of techniques for analyzing the communications, treating the information coming from the speeches of the participants investigated on a subject, so that it is possible to centralize the ideas and to categorize them thematically.
The research was carried out after approval by the Research Ethics Committee of the Federal University of Campina Grande, under Written Opinion number 2,118,518, dated June 13, 2017, in accordance with the ethical standards required by Resolution $466 / 2012$ of the National Health Council. ${ }^{27}$

\section{RESULTS}

40 mothers of children with Congenital Zika virus Syndrome from different cities of the State of Paraíba, being 18 and 39 years old, took part in the research. Regarding the declared skin color, the majority reported being brown (27 mothers), five said to be white, four, black, three, yellow and one did not know how to specify. On the marital situation, 29 had a fixed companion (married or in stable union), five were single, three, separated, two, divorced and one had been widowed. The children were aged between 1 year (12 months) old and 2 years and 2 months (26 months) old, with a mean age of 19.4 months.

The meanings found on what mothers of children with Congenital Zika virus Syndrome would say to other pregnant women of children with Zika virus-associated microcephaly diagnosis were classified into three thematic categories: the divine force that transforms the life of mothers; double feelings as a source for overcoming; and the meaning for the mothers' strength beyond the disease.

Category 1: The divine force that transforms the life of mothers

In order to endure the pain, accept challenges and face change in living with the syndrome, mothers maintained their faith in God, helping them to face the unpredictable reality of having a child with a disease with a still unknown prognosis. This faith was born from the special son, demonstrating this force in what they would say to other mothers in the same situation:

That she did not need to be so shaken, because God is in charge of everything to help. (M1)

That she had to have much faith in God himself. Because only those who know are the ones who have a child with a disability. Because I deem by myself, it's very difficult to take care... (M4)

I would say that she were not to be afraid, that Jesus gives comfort to people, right? For us to take care of, give strength ... at first we are afraid, but then... (M7)

That it is difficult, is it so, right? But for God, nothing is difficult. So ... a lot of strength and ask God for strength to continue and take care of the baby, do not abandon him/her (M15)

I would advise her, I would tell her: My daughter, have faith in God, do not despair, do not bow your head, God wants to see us smiling. So you go and look after your children, darling, if you have, go do the treatment, do not abandon, because when God sends the person with the disability to us, it is because we know how to fight, He will not give to a crazy person, who does not know how to fight, win in life, I only give good advices to people. (M26)

Hi woman, be very attached to God, that one can do everything with God, God may transform the possible and the impossible, and, if not, He does not load us beyond our strengths, He only gives what we can carry on, this is what I usually say... (M36) 
The described category was the strongest, appearing in most of the interviews. One also highlights the faith related to the gratitude of having a special child, where mothers revealed that God only gives a special child to the mother who knows how to carry on.

God knows of all things, that special child is not a rock of so much weight in our lives not. (M13)

I would say that God only gives a special son to a mother who is special [...] God only gives the burden that we can carry on, He will not give us what we can not do. (M17) It is for her to have a lot of faith in God and also give thanks, because it is not anyone who has the privilege of having a special child, God only gives what you can carry on. (M19)

l'd just say so, for her to accept, because we think it's a very difficult thing, but God resolves everything and we can overcome everything. Do not despair, because mothers usually despair when they know, because we never expect them to have such a child, but, if it came like this, it's because God knows that we can. (M20)

Ah, woman, it's so hard to say... patience, have strength, because thus, if God gave, she can carry on. He will not give us anything if we are not able to carry on. (M33)

If it were after pregnancy, she would be prepared, because the fight is ample, if you stick with God, because the fight is heavy, but there is also has a lot of gratification, right? You see that it is a special being sent by God. (M14)

From the words of the mothers, it was possible to see that the term "special son" is attributed to the interconnected feeling of being also a "special mother", in which they believe there is a divine predestination from the ability to accept the child as a received grace.

Category 2: Feelings in double a source for overcoming

The birth of a child with disabilities represents many challenges for the family. In this category, patience and love prevailed in the sense of being what children really need to have a dignified existence in the face of so many limitations and suffering.

If you are pregnant or want to become pregnant, take care of yourself, and regardless of how your child comes, give him/her enough love and care, because that is what they need. Because no one asked to come to the world. (M2)

I would just say that she would have to have a lot of patience, because it demands a lot of work. (M8)

That she loved him/her in double, that the love that we give them is 10,000 times greater than that of a normal child. And also care. (M21)

That she had a lot of patience, right? Because you have to be patient with these children, right? And she had a lot of love for the child, I say, it is what I have, right? Thus, I have a lot of patience with my daughter, too much love, doubled, right? Because one has to have... (M37)

The experience of these mothers is not easy: in addition to the accumulation of demands within the family unit, the daily struggle since pregnancy, as well as the exhaustive routine of caring for the children appear as fragilities that leave marks. At the same time, these women show that, despite all the difficulties, patience and love support in the coping process.

Category 3:The meaning of mothers' strength goes beyond the disease
This category brought us the idea that the dreams of the mothers remain, fed by the future of the children from an adaptation to an unexpected situation, that requires the conquest of coping strategies by the parents, showing the importance of living one day at a time, as verbalized in the speeches:

That, one day, God willing, may they walk, run, talk... It is going to take a little bit, but the time will come. (M10)

Thus, we should help each other, I would give her strength, say what l've been through, fortify... it's difficult, yes, but we have to accept that it is a child, it's difficult, yes, but we have to face it. I was going to lend a hand, explain what I went trough, through what am I passing today... (M18)

It is not easy, but it is trusting, it is having faith, because there is no other alternative, it is living day after day. Do not think about the past or future, it is to live the present. (M29)

May they have hope, because it is nothing on what people speak, that people make a commotion, that you think that children have nothing ahead. (M31)

Not only the impact of the diagnosis, the changes faced and the need to adapt to the situation, there is a force that drives these mothers, observed through speeches that give life and overcoming lessons.

\section{DISCUSSION}

In addition to the proper limitations of the syndrome, especially due to neuropsychomotor changes, there are challenges and changes in the lives of these families. Because mothers are the first social contact for the child, mothers often carry on a greater responsibility and personal resources are the solutions they find to face the reality of having a child with CZVS. As a form for overcoming, they often seek support and strength in faith, in the feelings for the child and in hope, being a comfort in times of crisis.

The expressions "spirituality", "religiosity" and "faith" are commonly used as synonyms, but their meanings are not the same, although, in the common sense, they are confusing. Spirituality holds a broader concept, which allows one to believe in a greater spiritual force, regardless of religion. Religiousness comes from an institutional structure to the effect of expanding a spiritual consciousness, from the religion. Faith confers peace and strength to bear the obstacles in everyday life, pointing out life's meaning and purpose. ${ }^{28}$

The expression of faith appeared as a source for backing and support for this confrontation. This faith is part of the spirituality, which denotes hope, believing in something as a safe haven, helping in fortifying the families. Faith gives meaning to the human beings in the face of unexpected life situations. ${ }^{29}$

For the parents of children with congenital heart disease interviewed at a Pediatric Intensive Care Unit in Rio Grande do Sul, the spirituality appeared as an imperative factor in coping with the process of getting a child falling sick, where the found manifestations were faith in healing and/or improvement and the possibility to return to healthy life..$^{29}$

In a study with mothers who faced the impact of the child's 
preterm birth and prolonged admission to the neonatal intensive care unit at a maternity unit in Natal/RN, one also identified the resource to spirituality, still depicting the hope in the child's survival, minimizing the emotional impact of the situation. ${ }^{30}$

Similarly, in a study carried out in Erechim RS, the faith of mothers of children with cerebral palsy encouraged the families in the search for acceptance and strength, bringing out new perspectives to face the disease, pointing out that faith is remarkable in different pathologies and hospitalizations. ${ }^{31}$ Very often, they seek this support as a way to overcoming, or as a comfort for difficult times. ${ }^{32}$

In a study carried out in Teresina/PI, mothers of children with hydrocephalus, after the initial shock, were committed to fighting for the child's survival and well-being, revealing that having a child with hydrocephalus was seen by them as a mission determined by God, and which should not be discussed, but simply accepted, ${ }^{33}$ coinciding with the found results.

For a mother, the illness of a child, related to the uncertainty about their future, is accompanied by intense care routines and divergent feelings about herself and the child, interfering, in a significant way, in her experience in maternity and quality of life. ${ }^{31}$ In the words of mothers in this study, through their experiences, a force became evident that reveals that God gives a special child to a special mother. Thus, " to have a special child is a divine ordeal for some people, requiring them the motherhood as an integral condition for survival". ${ }^{14: 2}$ For them, this mission is not meant for anyone, but given to someone fitting in built representations.

During gestation, women manifest distinct feelings, which represent their expectations and hope for the child being generated. It is important to highlight that each malformation shows individual particularities; apart from the different etiologies, they have different prognoses and diverse clinical implications, requiring specific care. From the perspective of the mothers, this special child is related to the sense of a disabled person, to the special child who needs differentiated assistance, not only with the inherent care of the congenital malformation or physical disability. ${ }^{34}$ And, from this care, the importance of patience and love emerges.

From surveying the personal resources to coping with the arrival of the child with congenital malformation, the feeling of becoming a mother is seen as a privilege for being chosen by God, being a way for justifying her ability to be a mother. ${ }^{35}$ "From looking at oneself by highlighting the changes arising from the chronicity of the child's illness to the transformations in family dynamics, mothers are walking along winding paths, sometimes with more optimism, sometimes more powerless in face of the disease's facticity". ${ }^{35: 1}$

In the bond existing between mother and child, in most situations, a relationship of dependence and necessity is created, where, in a family context, the mother holds the role of the owner of integral care, not sparing efforts to provide the best for the children, often renouncing their own personal and professional life, in order to contribute to their healthy development. ${ }^{36}$ In this attempt to cope with the difficulties and challenges inherent to the care, maternal care is marked by renunciation, these mothers become dedicated exclusively to the care of the child rather than performing their usual activities. ${ }^{33}$

In a study carried out in Timbaúba/PE, with mothers of disabled children, it was pointed out that, after accepting the disease, mothers begin to love their children and include them in the society, learning ways to overcome the prejudices that are built up, based on trust and self-esteem, resulting in the empowerment. These mothers are women marked by a life of exclusive dedication and total surrender to their children, where indissoluble bonds are built up, permeated by the true love between mothers and children, ${ }^{36}$ coinciding with our research.

It is important to consider that these children are at a stage of development, where, care is predominantly maternal. This situation is quite common in motherhood in general, even in the face of normality, where, it is clear that the mother becomes the custodian for this unconditional care to the child. Given the existence of some pathology, mother often turns exclusively to the disease and the need for self-care, ends up being neglected. Mothering is what expresses this force, to the effect that, often, mother ends up being annulled, having to give up her own life, staying away from her condition of being a woman, due to the child's existence.

By projecting living on the basis of the deficiency that their children have, this personal and social charge in performing the function that in the best way implies in suffering for a differentiated obligation. In this context, self-forgetfulness demonstrates the distance they have taken from their condition of being a woman, because they perceive themselves just as mothers of a child with a disability. ${ }^{36}$

Mothers with disabled children reveal the ability to adapt themselves to the experiences. And it is from this empowerment that these mothers are strengthened psychologically, facing difficulties, overcoming barriers and including children in the society. ${ }^{36}$ Through this recognition, the different forces of these mothers become explicit, making them more resilient in the face of the challenges and changes they face. And these children justify their strength in living, especially because they are the children of their mothers.

In a study in the Family Health Units from the urban area in a municipality of Paraíba, the experiences reported by mothers of disabled children with special health needs are unprecedented situations that become lived knowledge, serving as personal learning. Most mothers reported having experienced initial difficulties in caregiving actions, however, they recognized that it is possible to acquire the ability to learn and perform tasks that have never been performed before, confirming a positive attitude towards coping. ${ }^{37}$

The expectation on the evolution of the children, regardless of whether it materializes or not, moves these women, going after what is possible for the children to make satisfactory progress in the treatments. Depending on the degree of neurological impairment, each child has a differentiated reaction to the stimulus and this also needs to be respected and understood, falling to the "temporality of existence to illustrate past, present and future experiences". ${ }^{34}$ Mothers try to find ways to live 
with what is not considered normal by the society. ${ }^{36}$ At the same time that they feel themselves without a support base, this confrontation becomes necessary, in terms of having the strength to take care of the child, as something imperative. ${ }^{38}$ In addition, faced with the existential situation, there are countless uncertainties regarding the future of these children.

Despite the history marked by expressions of suffering, pain and overcoming, it is understood that the willpower and determination of these mothers in coping with difficulties emerge from the ability of these women to adapt themselves to the situation and find a new way for understanding life and experiencing maternity. To such an effect, being mother of a disabled child may be an enriching and personal transformation experience. ${ }^{32-2}$

Motherhood's experience, coupled with CZVS emerging reality, delimited a before and after in the women's lives, leading to a definitive situation in the lives of their children, which were irreversibly attained, becoming complex. In this context, a new working march appears, searching for acceptance and inclusion. ${ }^{5}$

In the inclusion process of child with CZVS into society, mothers face numerous challenges in front of their special needs. ${ }^{36}$ In this existing projection of the ideal child relative to the actual child, the present vulnerability and insecurity are considered as stressors, and lead to concerns about this child's survival and future. When severe neurological impairments result in mental retardation and motor impairment for the children, ${ }^{39}$ There is a concern about school and community insertion, coinciding with the results found in this study, showing that the children will need to start rehabilitation early, with multidisciplinary care in order to organize the routine. ${ }^{11}$

After the adjustment and adaptation process, mothers acquire the strength to fight and win, given the limitations imposed by the syndrome itself. From the acceptance, the inclusion of the child in society, with breaking of imposed prejudices, allows the construction of a bond between mother and child, previously fragile due to the mourning that they and their relatives were experiencing. ${ }^{36}$

In a study carried out in Recife/PE, from the approach of the stimuli and difficulties found by mothers of children with special needs during their children's rehabilitation process, it was possible to understand the need for acceptance for insertion and socialization in different social contexts. In some cases, although the child does not have a long life span, mothers showed the importance of not giving up, looking for possibilities so that children's limitations did not become impeditive in their growth and development, ${ }^{3}$ showing the sense of the force created by them beyond the disease.

In the research, it was shown that the majority of mothers demonstrated to be in the emotional reorganization phase, where the baby happens to be seen as a special child and the fragility experienced previously is replaced by an increasing capacity feeling in order to face the situation, and through the force found by the mothers, the motivation to continue the journey. After the experience of living and overcoming the news on the children's disabilities, mothers reported changes in their lives, valuing some factors and building up new feelings. They were now seeking to live, to enjoy the pleasant moments, to value and support their child in living with the disability. ${ }^{32-36}$

In parallel to the challenges, mothers learn to deal with time, trying to live each day at a time, respecting and accepting the limitations of their children, trying not to suffer in advance. Aligned with this result, plans and hope make them believe in a better world for their children.

\section{CONCLUSIONS AND IMPLICATIONS FOR PRACTICE}

To take care of a child with the Congenital Zika virus Syndrome diagnosis has involved emotional, social, economic and spiritual aspects and, in addition to a transformation and suffering process, that elapses mainly from the changes that happen in the family, showing the importance of a car network for these mothers and children, who inspire necessity for cares.

Despite all science advances, the unknown continues to be dealt with. Due to absence of information in the literature on the subject, specifically aimed at the care of children with CZVS and maternal experiences, further research should be carried out, enabling responses so that, thus, there may be awareness on the part of students, health professionals and society, helping to make these situations to be better faced by the families today. The reported experiences may contribute to qualifying the healthcare of the professionals who deal directly with these mothers in this context, and possibly favor the coping and adaptation of them and their families and of the new families that may come to have children with Congenital Zika virus Syndrome.

Furthermore, given the challenge to confronting a disease with few resources for diagnostics and treatment, there are some more extended proposals, among them, to strengthen Basic Health Care, create rooms where these women can have a place to take care of their children and themselves, invest in capacity building for the health professionals to expand the ability to listening, as well as institute intersectional actions in health, that may serve for research, teaching and extension from this experience.

\section{REFERENCES}

1. Roecker S, Mai LD, Baggio SC, Mazzola JC, Marcon SS. A vivência de mães de bebês com malformação. Esc Anna Nery [Internet]. 2012 Jan/ Mar; [cited 2018 Dec 10]; 16(1):17-26. Available from: http://www.scielo. br/scielo.php?script=sci_arttext\&pid=S1414-81452012000100003

2. Oliveira IG, Poletto M. Vivências emocionais de mães e pais de filhos com deficiência. Rev SPAGESP [Internet]. 2015; [cited 2019 Apr 10]; 16(2):102-19. Available from: http://pepsic.bvsalud.org/scielo. php?script=sci_arttext\&pid=S1677-29702015000200009

3. Silva AB, Damazio CR, Santana LS. Os desafios enfrentados pelas mães de crianças com necessidades especiais e a idealização do filho perfeito: vivências no CERVAC. O Portal dos Psicólogos [Internet] 2018; [cited 2019 Apr]. Available from: http://www.psicologia.pt/artigos/ ver_artigo.php?os-desafios-enfrentados-pelas-maes-de-criancas-comnecessidades-especiais-e-a-idealizacao-do-filho-perfeito-vivencias-no cervac $\&$ codigo $=\mathrm{A} 1181$

4. Kruel CS, Lopes RCS. Transição para a parentalidade no contexto de cardiopatia congênita do bebê. Psic Teor Pesq [Internet]. 2012; [cited 
2018 Nov 16]; 28(1):35-43. Available from: http://www.scielo.br/scielo. php?pid=S0102-37722012000100005\&script=sci_abstract\&tIng=pt. DOI: http://dx.doi.org/10.1590/S0102-37722012000100005

5. Pinheiro DAJP, Longhi MR. Maternidade como missão! A trajetória militante de uma mãe de bebê com microcefalia em PE. Cad Gen Divers [Internet]. 2017 May/Aug; [cited 2019 Jun 2]; 3(2):113-32. Available from: https://portalseer.ufba.br/index.php/cadgendiv/article/ view/22216

6. Albuquerque MFPM, Souza WV, Araújo TVB, Braga MC, MirandaFilho DB, Ximenes RAA, et al. Epidemia de microcefalia e vírus Zika a construção do conhecimento em epidemiologia. Cad Saúde Pública [Internet]. 2018; [cited 2019 Apr 9]; 34(10):e00069018. Available from: http://www.scielo.br/pdf/csp/v34n10/en_1678-4464-csp-3410-e00069018.pdf

7. Fundo das Nações Unidas para a Infância (UNICEF). Redes de Inclusão: garantindo direitos das famílias e das crianças com Síndrome Congênita do Zika vírus e outras deficiências. Brasília (DF): UNICEF; 2018

8. Diniz D. Zika: do sertão nordestino à ameaça global. Rio de Janeiro: Civilização Brasileira; 2016. 192 p.

9. Ministério da Saúde (BR). Secretaria de Vigilância em Saúde. Protocolo de Vigilância e Resposta à Ocorrência de Microcefalia e/ou Alterações do Sistema Nervoso Central (SNC). Brasília (DF): Ministério da Saúde; 2015.

10. Salge AKM, Castral TC, Sousa MC, Souza RRG, Minamisava R, Souza SMB. Zika virus infection during pregnancy and microcephaly in newborns: an integrative literature review. Rev Eletr Enferm [Internet] 2016; [cited 2019 Mar 11]; 18:e1137. Available from: http://dx.doi. org/10.5216/ree.v18.39888

11. Reis JC, Santos PS, Barata MFO, Falcão IV. Abordagem da terapia ocupacional a bebês com microcefalia: uma experiência no estágio curricular. Rev Interinst Bras Ter Ocup (Rio de Janeiro) [Internet]. 2018 [cited 2018 Nov 14];2(1):212-7. Available from: https://revistas.ufrj.br/ index.php/ribto/article/viewFile/12642/pdf

12. Pimentel PLB, Furtado FMF, Saldanha AAW. Vulnerabilidades acerca do cuidado na perspectiva de mães de bebês com microcefalia. Psicol Estud [Internet]. 2018; [cited 2019 Jan 2]; 23:e40178. Available from: http://periodicos.uem.br/ojs/index.php/Psicol Estud/article/view/40178

13. Henriques CMP, Duarte E, Garcia LP. Desafios para o enfrentamento da epidemia de microcefalia. Epidemiol Serv Saúde [Internet]. $2016 \mathrm{Jan} /$ Mar; [cited 2018 Jun 14]; 25(1):7-10. Available from: http://www.scielo. $\mathrm{br} / \mathrm{scielo}$.php?script=sci arttext\&pid=S2237-96222016000100007. DOI: http://dx.doi.org/10.5123/s1679-49742016000100001

14. ZIKA. Directed by Débora Diniz. Producers: Luciana Brito, Sinara Gumiere. Brasília (DF): Itinerante filmes; 2016. (29 min).

15. Diniz D. Zika virus and women. Cad Saúde Pública [Internet]. 2016 May; [cited 2018 Nov 10]; 32(5):e00046316. Available from: http://www. scielo.br/pdf/csp/v32n5/1678-4464-csp-32-05-e00046316.pdf

16. Brasil. Senado Federal. Constituição da República Federativa do Brasil: Texto constitucional promulgado em 5 de outubro de 1988 , com as alterações determinadas pelas Emendas Constitucionais de Revisão nos 1 a 6/94, pelas Emendas Constitucionais nos 1/92 a 91/2016 e pelo Decreto Legislativo no 186/2008. Brasília (DF) Senado Federal; 2016.

17. Eickmann SH, Carvalho MDCG, Ramos RCF, Rocha MAW, Linden Vvd, Silva PFS. Síndrome da infecção congênita pelo vírus Zika. Cad Saúde Pública [Internet]. 2016 Jul; [cited 2019 Apr 7]; 32(7):e00047716. Available from: http://www.scielo.br/scielo. php?script=sci_arttext\&pid=S0102-311X2016000700601\&lng=en

18. Amatuzzi M. Experiência: um termo chave para a Psicología [Internet]. Memorandum; 2007. [cited 2010 May 22]. Available from: http://www. fafich.ufmg.br/ memorandum/a13/01Amatuzzi.pdf

19. Boff L. Saber Cuidar. Ética do humano - compaixão pela terra Petrópolis: Vozes; 1999.

20. Minayo MCS. Pesquisa Social: teoria, método e criatividade. 18a ed Petrópolis: Vozes; 2001.
21. Lima ACS, Magalhães CSCA, Assis SM, Costa, Silva SHS. O desafio do conhecimento. Rev Eletr Inter Legere [Internet]. 2014 Jan/Jun [cited 2019 May 22]; 14:1-8. Available from: https://periodicos.ufrn.br/ interlegere/article/download/4873/4272/

22. Teodoro IPP, Rebouças VCF, Thorne SE, Souza NKM, Brito LSA Alencar AMPG. Interpretive description: a viable methodological approach for nursing research. Esc Anna Nery [Internet]. 2018 Mar; [cited 2019 May 20]; 22(3):e20170287. Available from: http://www. scielo.br/scielo.php?script=sci_arttext\&pid=\$141481452018000300 $601 \& \operatorname{lng}=\mathrm{en}$

23. AgendaPB: CER de Campina Grande amplia de 7 mil para mais de 50 mil atendimentos por ano. Campina Grande: Câmara Municipal 2018. [cited 2019 May 20]. Available from: http://agendapb.com br/cer-de-campina-grande-amplia-de-7-mil-para-mais-de-50-milatendimentos-por-ano

24. Mccubbin MA, Mccubbin HI. Families coping with ilness: the Resiliency Model Family Stresse, Adjustment, and Adaptation. In: Danielson C, Hamel-Bissell B, Winstead-Fry P, eds. Families, Health \& Ilness. Perspectives on coping and intervention. St Louis: Mosby-Year Book; 1993. p. 21-63.

25. Fontanella BJB, Luchesi BM, Saidel MGB, Ricas J, Turato ER, Melo DG. Amostragem em pesquisas qualitativas: proposta de procedimentos para constatar saturação teórica. Cad Saúde Pública [Internet]. 2011 Feb; [cited 2019 Apr 10]; 27(2):388-94. Available from: http://www.scielo.br/scielo.php?script=sci_arttext\&pid=S0102311X2011000200020\&Ing=en

26. Bardin L. Análise de Conteúdo. São Paulo: Edições 70; 2011.

27. Brasil. Conselho Nacional de Saúde. Resolução № 466 de 12 de dezembro de 2012. Brasília (DF): Diário Oficial da União; 2012.

28. Borges MS, Santos MBC, Pinheiro TG. Representações sociais sobre religião e espiritualidade. Rev Bras Enferm [Internet]. 2015 Jul/Aug; [cited 2019 May]; 68(4):609-16. Available from: http://www.scielo.br/scielo. php?script=sci_arttext\&pid=S0034-71672015000400609\&lng=en. http://dx.doi.org/10.1590/0034-7167.2015680406i

29. Barreto TSM, Sakamoto VTM, Magagnin JS, Coelho DF, Waterkemper R, Canabarro ST. Vivência de pais de crianças com cardiopatia congênita: sentimentos e obstáculos. Rev Rene [Internet]. 2016 Jan/Feb; [cited 2018 Jan 12]; 17(1):128-36. Available from: http:// periodicos.ufc.br/rene/article/view/2625. DOI: 10.15253/21756783.2016000100017

30. Véras RM, Vieira JMF, Morais FRR. A maternidade prematura: o suporte emocional através da fé e religiosidade. Psicol Estud [Internet]. 2010; [cited 2017 Jun 15]; 15(2):325-32. Available from: http://www. scielo.br/scielo.php?pid=S1413-73722010000200011\&script=sci abstract\&tlng=pt

31. Lazzarotto R, Schmidt EB. Ser mãe de crianças com paralisia cerebral: sentimentos e experiências. PERSPECTIVA Erechim [Internet]. 2013 Dec; [cited 2017 Jun 14]; 37(140):61-72. Available from: http://www. uricer.edu.br/site/pdfs/perspectiva/140_373.pdf

32. Oliveira MC, Moreira RCR, Lima MM, Melo RO.Vivências de mães que tiveram filhos com microcefalia. Rev Baiana Enferm [Internet]. 2018; [cited 2019 Apr 8]; 32:e26350. Available from: file:///C:/Users/susana/ Downloads/26350-102758-2-PB.pdf

33. Costa ECL, Veloso RA, Feitosa JJM. Crianças portadoras de hidrocefalia: dificuldades e vivência das mães. Rev Interd [Internet]. $2013 \mathrm{Jan} / \mathrm{Feb}$ [cited 2017 Jul 14]; 6(1):71-9. Available from: https://revistainterdisciplinar. uninovafapi.edu.br/index.php/revinter/article/view/17

34. Pinheiro DAJP. Dossiê - Gênero, cuidado e famílias "Mãe é Quem Cuida": a Legitimidade da maternidade no discurso de mães de bebês com microcefalia em Pernambuco. Mediações [Internet]. 2018 Dec; [cited 2019 Mar 25]; 23(93):132-63. Available from: http://www. uel.br/revistas/uel/index.php/mediacoes/article/view/34324. DOI: 10.5433/2176-6665.2018.3v23n3p132.

35. Souza MA, Melo LL. Being a mother of child hospitalized with a chronic illness. REME Rev Min Enferm [Internet]. 2013 Apr/Jun; [cited 2019 May 20]; 17(2):362-73. Available from: http://www.reme.org.br/artigo/ detalhes/655 
36. Guerra CS, Dias MD, Ferreira Filha MO, Andrade FB, Reichert APS, Araújo VS. From the dream to reality: experience of mothers of children with disabilities. Texto Contexto Enferm [Internet]. 2015 Apr/Jun; [cited 2018 Jul 13]; 24(2):459-66. Available from: http://www.scielo.br/scielo. php?script=sci_arttext\&pid=S0104-07072015000200459. DOI: http:// dx.doi.org/10.1590/0104-07072015000992014

37. Assis FAG, Pinto MB, Santos NCCB, Torquato IMB, Pimenta EAG. Family child with special needs of health: the process of coping and adaptation. Ciênc Cuid Saúde [Internet]. 2013Oct/Dec; [cited 2017 Jun 14]; 12(4):73643. Available from: http://periodicos.uem.br/ojs/index.php/CiencCuidSaude/ article/view/18826. DOI: 10.4025/cienccuidsaude. v12i4.18826
38. Lise F, Schwartz E, Milbrath VM, Santos BP, Feijó AM, Garcia RP. Criança em tratamento conservador renal: experiências das cuidadoras familiares. Texto Contexto Enferm [Internet]. 2017; [cited 2018 Jun 30]; 26(3):e1110016. Available from: http://www.scielo.br/scielo. php?pid=S0104-07072017000300308\&script=sci_abstract\&tlng=pt. DOI: http://dx.doi.org/10.1590/0104-07072017001110016

39. Miranda-Filho DB, Martelli CMT, Ximenes RAA, Araújo TVB; Rocha MAW, Ramos RCF, et al. Initial Description of the Presumed Congenital Zika Syndrome. Am J Public Health [Internet]. 2016 Apr; [cited 2019 May 18]; 106(4):598-600. Available from: https://www.ncbi.nlm.nih.gov/pmc/ articles/PMC4816005/ 